\title{
Logistics and Agri-Food: Digitization to Increase Competitive Advantage and Sustainability. Literature Review and the Case of Italy
}

\author{
Marco Remondino *(D) and Alessandro Zanin (D) \\ Department of Economics, University of Genoa, 16126 Genova, Italy; alessandro.zanin@edu.unige.it \\ * Correspondence: marco.remondino@economia.unige.it
}

check for updates

Citation: Remondino, M.; Zanin, A. Logistics and Agri-Food: Digitization to Increase Competitive Advantage and Sustainability. Literature Review and the Case of Italy. Sustainability 2022, 14, 787. https://doi.org/ $10.3390 /$ su14020787

Academic Editor: Piotr Prus

Received: 7 November 2021

Accepted: 8 January 2022

Published: 11 January 2022

Publisher's Note: MDPI stays neutral with regard to jurisdictional claims in published maps and institutional affiliations.

Copyright: (C) 2022 by the authors. Licensee MDPI, Basel, Switzerland. This article is an open access article distributed under the terms and conditions of the Creative Commons Attribution (CC BY) license (https:// creativecommons.org/licenses/by/ $4.0 /)$.

\begin{abstract}
This paper examines the current challenges faced by logistics with a focus on the agri-food sector. After outlining the context, a review of the literature on the relationship between logistics and strategic management in gaining and increasing competitiveness in the agri-food sector is conducted. In particular, the flow of the paper is as follows: after examining the aforementioned managerial problem and its broader repercussions, the paper proceeds to address two main research questions. First, how and by which tools can digitization contribute to improving supply chain management and sustainability in logistics? Second, what are the main managerial and strategic implications and consequences of this for the agri-food sector in terms of efficiency, effectiveness, cost reduction, and supply chain optimization? Finally, the paper presents Italy as a case study, chosen both for its peculiar internal differences in logistical infrastructures and entrepreneurial management between Northern and Southern regions (which could be at least partially overcome with the use of new technologies and frameworks) and for the importance of the agri-food sector for the domestic economy (accounting about $25 \%$ of the country's GDP), on which digitization should have positive effects in terms of value creation and sustainability.
\end{abstract}

Keywords: logistics; agriculture; agri-food; agri-tech; strategic management; digitization; IoT; Big Data; artificial intelligence; Blockchain

\section{Introduction}

International trade, global politics and new technologies are facing radical changes which result in great complexity and uncertainty.

The world of shipping, transport and logistics is developing in a context of increasing globalization, which has enabled production processes to enjoy a substantial reduction in transport costs and an increase in efficiency with considerable benefits for the growth of the global economy [1]. In addition to these macroeconomic developments, there are endogenous challenges in the shipping world characterized by limited hold capacity, horizontal and vertical integration processes, tensions in the shipbuilding industry and increasing regulation $[2,3]$.

In the port sector, for instance, the imperative to maintain the efficiency of loading and unloading operations and the need to raise capital for infrastructure development are compounded by the challenges of environmental protection and the demands of local communities [4-6]. The digital economy is reshaping transportation [7-9] with, for instance, the aim of increasing efficiency levels, achieving greater transparency and traceability of logistics chains, and reducing negative externalities (e.g., accidents, environmental and road damage, congestion, oil dependence, etc.) resulting from specific logistical activities. Despite the opportunities offered by new technologies, digitization represents a major challenge for many supply chains in maintaining the competitiveness of a structure that, by its nature, is located in a given territory and serves its logistics chains $[10,11]$. Digitization processes require specific strategic planning, business process reengineering, and definition 
of specific KPIs [12] in order to, on the one hand, avoid social tensions and, on the other, to foster the development of a logistics system focused on improving value chains and safeguarding the welfare of local communities and the environment.

Logistics integration shared by companies is a major goal [13]; by closely coordinating different logistics activities along the supply chain [14], it is possible to optimize the flow of materials with customer requirements, thereby increasing reliability and speed of response to market. In addition, the role of digitization in logistics can greatly improve sustainability, as shown in several recent research papers [15-18]

For these reasons, the present paper aims at analyzing the specificity of logistics at the level of strategic management through an extensive literature review, along with the ways in which digitization can help to improve specific aspects of both efficiency and sustainability, with a particular focus on the agri-food sector.

The numerous benefits that can potentially be achieved by logistics integration alongside the supply chain appear particularly relevant for the companies operating in the agri-food industry [19], where the profound changes in the competitive scenario caused by the evolution of food demand and its "short supply-chain" [20], the progressive growth of the international dimension of markets, and the dominant role assumed by large-scale distribution chains [21] all require a rethinking of operational logic and management models.

In particular, the evolution of consumer preferences has led to exponential growth in the range and variety of agri-food products available [22], while the growing role of large-scale distribution has forced agri-food companies to adapt to distribution needs through frequent deliveries, palletized loads, and specific technologies [23]. The rational management of logistics along the supply chain in this context plays a fundamental role through the integration of physical and information flows.

Therefore, following a general analysis of the role of logistics in management, two main research questions are addressed in this paper: (1) What contributions can digitalization bring to the logistics sector and supply chain optimization? and (2) What are the direct effects in the agri-food sector (with a focus on the Agriculture 4.0 paradigm), an industry which relies heavily on logistics for a series of very significant aspects such as the high perishability of products and the need to transport them to markets far away from production.

After this part, the paper presents the case study of Italy, a country that could greatly benefit from vast investments in digitization and new technologies in the aforementioned areas for two main reasons.

First, transportation and logistics have been fundamental in Italy since the times of Romans; yet today, many issues at the infrastructural level, especially the logistical divide between Northern and Southern Italy [24] remain to be addressed and could greatly benefit from many of the digital technologies examined in this paper.

Second, the fundamental importance of the agri-food sector to Italy, amounting to around $25 \%$ of its GDP, means that the ability to employ the most recent and incoming digital technologies for logistics to support this specific industry and help close the infrastructural gap between Northern and Southern Italy is a strategic and competitive imperative for the country.

The difficulties associated with the management and organization of logistics in the agri-food system are even more pronounced when looking at the reality of Southern Italy, characterized by the prevalence of small- and medium-sized enterprises operating as subcontractors which, partly because of the aforementioned infrastructural gap between the two geographical realities [24], do not take full advantage of the opportunities offered by direct relations with customers and by the "Made in Italy" merchandise mark. 


\section{Strategic Management in Logistics: A Balance between Connectivity and Sustainability}

Logistics has always been an essential and strategic process for companies [25], coordinating the activities of the various players involved in the transport of goods from the production market to the consumer market to optimize the entire supply chain both in operational and economic terms [26-29].

One of the main elements of the competitive advantage in logistics at both the country and company operation levels is connectivity [30,31], which can be defined in terms of the quality of the infrastructure available on the territory as well as in terms of the number of connected nodes (maritime, air and intermodal services) [32,33].

This is a matter of both physical infrastructure and intangible network and node infrastructure for reasons of both efficiency and greater safety and environmental sustainability in terms of lower emissions and accidents [34,35].

Competition in today's economic world is mainly based on the speed of access to markets $[36,37]$ national and international, and, moreover, on the efficiency of logistics chains, which have a decisive influence on the selling price of products [38]. Greater efficiency in infrastructure management methods, along with the need to digitalize processes and procedures, is essential $[39,40]$.

In addition to the fundamental connectivity factor, the logistics sector is one of the most exposed in terms of environmental sustainability [41] as both transport and storage of goods are activities that produce $\mathrm{CO}_{2}$ emissions [42-44], waste, and land consumption [45], and determine other negative externalities as well, such as accidents and traffic congestion. While at a first glance this sector might thus appear to be somehow opposed to the quest for greater connectivity, on the contrary, sustainability should be not only a social duty of companies but a lever for growth and competitiveness [46-48]. Logistics, in fact, has an environmental cost for which companies are responsible, and of which they need to be aware if they want to improve the environment in which they operate on a large scale and in terms of corporate social responsibility (CSR) [49,50].

Critical issues arising from logistics and consumption choices are never neutral, and not all distribution models are sustainable. That is where connectivity and sustainability converge as a task for strategic management: greater fragmentation implies higher economic and environmental costs, as these are closely related to the timing and frequency of deliveries [45,51,52].

Hence, the aim of strategic management should be to find environmentally-friendly solutions to increase connectivity for the logistics chains [53], e.g., reduction/reengineering of packaging to optimize storage and maximize capacity and use of recyclable materials to achieve a reduction of wastes $[54,55]$ along with other capacity management strategies and technologies. As an example, digitization and consequent dematerialization of procedures and documents $[56,57]$ with an accurate choice of increasingly sustainable modal combinations results in a significant reduction in errors during the information transfer phases, thus reducing waste [58,59]. In addition, accurate measurement and reporting of greenhouse gas emissions from the movement of goods and related logistics operations could certainly accelerate the reduction of negative environmental impacts [44,60]. Measuring emissions helps companies to improve their supply chain by making procurement costs more efficient and by choosing more sustainable modes of transport [61].

In the agri-food sector, logistics is strategic for companies and represents a key element in determining their success $[19,62,63]$, yet logistics is often more complex to manage here than it is in other industries. The complexity of logistics in the agri-food industry is due to the characteristics of the specific products, the required logistical processes to keep them fresh and good, and the network itself [64], as very far away markets must be served, some of which are characterized by a low level of connectivity (e.g., some African regions).On the other hand, complexity is accentuated by the increase in service expectations from the end-user in terms of punctuality, accuracy, flexibility and timeliness [65]. 
The strategic importance of logistics for company competitiveness is therefore present for all perishable food products and this, as mentioned, implies an increase in the complexity of its specific aspects, deriving not only from the creation, control and monitoring of green cold chain networks [66] at all levels but, substantially, from the scarce standardization of loading units and the different specific packaging requirements for the various product classes, something that could be highly improved with intelligent information sharing and other digital techniques.

\section{Digitization and New Technologies to Support Logistics and Its Sustainability}

During the next decade, technological innovation will determine a strong evolution of all transport systems [67], and the strategic choices concerning the infrastructural and urban planning of the territory will necessarily have to deal with this new scenario for sustainable mobility as it will lead to new needs and new use of the spaces necessary for the transport of people and goods [68].

As underlined in the previous paragraph, it is necessary at both the level of political economy and at the level of business management to define the strategic priorities for intervention in the logistics sector, or rather, to define macro-objectives and criteria in order to guide choices. This development will have a significant impact on territorial organization, e.g., in the direction of smart cities.

In the near future, the field of mobility will undergo a technological renewal that will have profound effects on travel habits and logistics [69,70].

Automation in the field of land transport is rapidly moving in the direction of replacing the active driver of the vehicle with an artificial pilot [71,72], relegating the role of the human being to a mere supervisor of the system. In this scenario, the first effect, which will become a necessity as early as the next decade, is to rethink the whole mobility system in order to take advantage of the benefits that the new technologies can bring to the community, rather than only to individuals or companies [60,73].

As to the pure issue of connectivity and mobility, it is possible to identify three different development trajectories which are affecting the main players in the industry at the world level, namely, innovations linked to the use of new communication technologies and new ways of owning the collective transport system as summarized under the acronym Mobility as a Service (MaaS) [74], prospects for autonomous driving [72] destined to bring about profound changes in the functionality of road networks, and the techniques of automatic vehicle queuing or platooning [75].

These elements, especially if considered as a whole, outline a reference scenario for the future of mobility that is significantly different from the current situation, determining problems and challenges that require a strategic capacity at an organizational and management level, even more so than at a technological level [76]. For example, these technological innovations will likely lead to an ever-increasing interdependence between road and vehicles [77], and consequently investment efforts will need to be increasingly concentrated in this direction. More generally, future scenarios will always show an increase in the mobility of people, as well as of vehicles alone, when they are equipped with autonomous driving.

In many cases, in order to improve the efficiency of these systems and connectivity as a whole it will be necessary to intervene in the infrastructures itself, providing a series of information supports for the vehicle which will refer less and less to data obtainable from the on-board systems [78,79] by using cloud systems and shared data instead [80]. Additionally, in the connectivity field the social cost of the obsolescence of the networks and infrastructures cannot be ignored [81], as it relates not only to the costs incurred in ensuring their extraordinary maintenance (if not their replacement) but to the damage caused by their possible loss of functionality as well. However, this need could be seen as a partially favorable condition for adapting specific infrastructures to the needs of the future, transforming maintenance into a true retrofitting [82] aimed at ensuring new functionality for large parts of the existing network; in this case, efficiency can thus go hand in hand with sustainability and efficient resource management. 
Another very important issue when dealing with the topic of connectivity in logistics is the port-territory relationship [83]; this is one of the basic elements for the development of the economy of territories and their sustainability $[84,85]$, especially from the perspective of innovative logistics. In this case, the use of digital technologies for the supply chain is a fundamental lever to enable a new business model $[76,86]$ with innovative logistics practices.

The logic whereby the need to create an information environment is highlighted is that of developing a management platform that implements and enables the business model through the integration of information from various actors, objects and agents with, e.g., Internet of Things (IoT) [87] technologies, enabling an effective and low-cost information exchange.

Digital innovations can enable logistics operators to promote efficiency and lower costs [88-91] as well as to pursue new business opportunities, for example through advanced data management techniques such as Big Data (BD), Data Mining (DM), and Business Intelligence (BI), to name a few. Data has always been at the heart of logistics, and new technological advances in data collection, processing, and simulation [92] offer the opportunity for companies to better achieve their goals, strategically, e.g., by optimizing routes [93-95], operationally, and tactically, i.e., optimizing the number of trucks and drivers as well as monitoring deliveries in real-time by introducing new technologies such as artificial intelligence and augmented reality [96]. Digital platforms thus represent a new frontier for logistics, as they open up new opportunities and new business models [97].

As noted earlier, logistics is strictly connected with the overall operational efficiency of a business; thus, the concept, essence and objectives of the application of digitization in logistics may often involve other economic areas in order to increase competitiveness and reduce environmental impact by increasing efficiency in the use of certain resources. This is the vision of creating "green logistics" [98], i.e., logistics as an element of sustainable development. Many countries, whether developed or emerging economies, are working towards sustainable development because, as pointed out, a close relationship exists between logistics, the environment and natural resources, better logistics management; employing digital technologies will therefore likely contribute to solving the problems of sustainable development.

To this extent, a specific and very important node for the evolution of logistics involves ports, which constitute a fundamental element of infrastructure for most long-range transport activities. The port system, in fact, plays a pivotal role in international trade, goods and passenger transport, and is a vital element in the development of an efficient and sustainable intermodal transport network. The modification needed to increase the efficiency of a port often requires the use of digital technologies, eventually turning it into a "smart port" [99,100].

Any transition process, of course, needs a strong component of training, change management, transformation and skills development to properly address the new challenges, in particular the challenges of the new smart and green ports [101].

Becoming "smart" means becoming leaner and more efficient while in turn becoming more attractive and competitive. Artificial intelligence (AI) [102], IoT [103], BD [104], and blockchain [89] platforms, as well as other technologies, can enable ports to manage workflows and working conditions more efficiently by modeling processes for more effective, clean and environmentally friendly operations.

In the context of connectivity and network creation, the development of a smart port increases its ability to cultivate and develop cooperation between shippers, logistics facilities, and port terminals as well as carriers and logistics operators, thus fostering cooperation and value creation in the broader sense.

In dealing with sustainability, maritime transport accounts for an important and growing share of negative externalities [105], often in densely populated areas. Without going into specifics, these issues concern the pollution produced by ships standing on the 
quayside, noise, greenhouse effect and vibrations produced by activities in the port area and by the handling of goods.

In the more logistics field more generally, there are several activities that have proven their effectiveness, such as investing in the training of new professionals [106,107] and in the development of new and innovative logistics centers, which exploit new and more innovative warehouse techniques.

The reorganization of logistics chains using advanced technologies such as IoT, BD analytics, and autonomous robotics have the power to transform the supply chain management model from a linear business model into an integrated model [59] in which information flows omnidirectionally. These technologies are generating economic benefits by reducing costs while making production more responsive to consumer demand and stimulating employment $[108,109]$. The implementation of networking strategies is moving in this direction as well, and integration is considered to be the key to sustainable development [110]; i.e., the aim is to ensure integration between economic, social and environmental policies to achieve development that can be defined as sustainable in all respects. Digitization and sustainability in different sectors have been recognized as closely connected by several studies [111,112].

Digitization of the supply chain enables companies to address new demand and supply-side challenges as well as to maintain expectations for efficiency improvements. It enables a new supply chain which is faster and allows new approaches to product distribution, e.g., predictive analysis of internal data (e.g., demand) and external data (e.g., market trends). This new supply chain is more flexible (through new technologies and ad hoc and real-time planning against changing demand or supply situations) and more atomized given the demand for increasingly customized products, which incentivizes micro-segmentation of demand. It is more accurate, e.g., through the use of drones for last-mile delivery [96], and more efficient, through the integration of data from suppliers and service providers into a "supply chain cloud" $[113,114]$, ensuring that all involved parties decide on actions based on the same facts.

In the future, "predictive shipping" will probably emerge as a paradigm [115], with products being shipped even before the customer places an order based on preferences and previous purchases. A customer's order can then be matched to a shipment already in the logistics network (being transported to the customer's region) and the shipment redirected to the customer's exact destination. The new supply chain will have an impact on all areas of supply chain management.

Data, transformed into information [116,117], allows the creation of models useful on for developing organizational processes and identifying interdependence between variables $[118,119]$. The application of this in logistics through $\mathrm{BI}$ and $\mathrm{BD}$ techniques allows data from strategically placed sensors to be processed and, working out the best routes or combinations of routes in terms of cost, time and sustainability [120]. Blockchain is a growing technology creating a new way of interacting in the supply chain [121]; trust is established by consensus between parties and supported by the technological framework itself, thus removing the need for an intermediary. This goes far beyond basic transactions; in fact, efficiency can be improved along with goods safety and traceability to quickly check the origin of goods and detect the extent of any contamination problems.

The connectivity issue in building a sustainable freight transport chain necessitates the integration of port and rail infrastructure $[122,123]$ in order to make the entire logistics chain competitive, from ports to hinterland [124], by investing resources in "green" corridors linking ports and rail hubs. The investment plan should provide for a path divided into successive steps that will allow a structure to contribute to achieving the objective set by environmental policies. This must include increasing energy efficiency and building the infrastructure needed to lay the foundations for the transition [125].

Even if not immediate, the transition to a new energy system which marginalizes the system of producing electricity through oil or gas in favor of implementing a system powered by clean and renewable sources such as solar or wind power is very important; 
however, other energy sources such as geothermal are indispensable in this respect, as is energy produced from biomass [126,127].

The systemic approach to the decarbonization $[128,129]$ of the transport sector is favored by the digitization of specific processes, as shown in several research studies, e.g., [130,131], thus leading to an improved circular economy [132].

\section{Optimizing Processes in the Agri-Food Industry through Digitization and Technology}

Current demand trends in the agri-food market are forcing operators to stress logistics activities in order to respond to the ever-increasing customization of consumer demand. It is therefore becoming strategic to introduce innovations to streamline the business model in the supply and distribution chain of this specific industry [133]. For example, the model of central purchasing bodies [134], which can achieve significant economies of scale by developing bargaining power, do not permit the consolidation of supplies (and therefore shipments), resulting in significant logistical inefficiencies which aggravate the supply chain, with accompanying higher costs and a loss of efficiency and flexibility.

Digital technology is disrupting the agricultural world [135] to an extent that has often been referred to as Agriculture 4.0 or AgriTech [136,137]; through the updating of processes, technologies and systems, there is a tendency to achieve more efficient farming methods and provide sustainable and environmentally friendly food solutions [138].

Integration in the context of Agriculture 4.0 refers to the adoption of specific information systems capable of interacting with suppliers and customers [139], either to exchange information by vertical integration, or to interacting with different companies operating in the same supply chain even if and when they are apparently competitors, that is, by horizontal integration and co-opetition [140]. To better understand this, it is possible to draw a parallel in the automotive sector, where integration platforms allow the exchange of information between designers of the car body, designers of the molds used to produce the body, designers of the components, and above all (the challenge to be taken up in the agricultural field) the exchange of information between several producers, even competitors, with access to common platforms (very often chassis, engines, or other non-aesthetic details shared in the supply chain).

It is, therefore, fundamental to implement broad programs and new investments in order to integrate the new technologies that can positively affect the agricultural environment in the coming years and the connected value-added logistic processes. A real revolution in the agricultural sector [141] that involves processes integrated with all the digital technologies that can increase interconnection and cooperative pooling of resources.

The focus is on a "precision agriculture" [142-144] that through IoT, BD and other aforementioned technologies can reach levels of efficiency that were once unthinkable, helping to face the new challenges of population growth, climate change, resource scarcity and food waste [145].

As already pointed out, logistics in the agri-food sector is particularly complex, even when compared to other industries; hence, the use of digitization could be particularly successful in this area. Day-to-day operations in the agri-food industry throughout the supply chain already generate vast amounts of data which can be used to improve each company's specific task. For instance, if the data from that huge pool were made dynamic and usable in predictive models [146], farmers could achieve better productivity and lower operating costs. Precision farming would therefore enable farmers to do more with fewer resources and, through the identification of the essential and key "segments" of the production chain, to achieve more effective and immediate decision making and eventually a higher return on investment. Utilizing data and simulation, it is possible to identify specific areas of a business that could be better developed to provide better sustainability results $[119,147]$. Through the intelligent use of data, it is possible for farmers to better understand their production practices and what changes within their own structure can generate more value. Hence, from these data, virtual educational models such as business games [148] can be implemented to create new professional figures with higher knowledge. 
Smarter, more efficient farming techniques [149] and human resources take full advantage of BD and new technologies for the benefit of the entire supply chain. This technology has the potential to benefit the entire supply chain [150] and will play an increasingly important role in the transformation of the agricultural sector.

The role of $\mathrm{BD}$ is one of change, probably the biggest change witnessed in agricultural operations in this century [151]. BD will make the entire chain more competitive and profitable, and these benefits will trickle down as the agricultural sector is empowered by more information, having such an effect as to increase margins throughout the whole supply chain while increasing quality to meet the demands of buyers both local and international.

The image of BD as only for Big Farming is beginning to fade; increasingly, more farms of all sizes are realizing the importance of being able to precisely measure their performance [152]. Farmers can undergo an experimental business-oriented approach to use solutions that work for them by testing and implementing one improvement at a time over several seasons and using BD as an assessing and decision-support tool to take their business one step at a time towards a more sustainable and profitable future.

The use of IoT by agricultural devices [153] is set to become the norm, not the exception. Sensors are already being used to monitor soil nutrition [154], temperature, and moisture; through IoT, all of these systems can be connected, eliminating the need to repeatedly enter data into multiple and sometimes unrelated applications that do not communicate with each other. Hence, one further step is needed: to imagine a farm where all relevant information is automatically and seamlessly unified, allowing the farmer and the entrepreneur to do the work they need to do [155]. In this regard, the software is becoming increasingly interoperable (i.e., different apps can share and use the same data sets), significantly reducing the financial and time costs of human error $[156,157]$.

Reconnaissance drones [158] are another example of this. They provide an "eye from the sky", searching for pests or dry spots and assessing crops by spotting weeds and diseased crops.

As for the sustainability issues, intensive agriculture presents obvious sustainability problems and there is a growing need for more environmentally friendly support technologies, such as technologies that promote the biodiversity of the species being grown while reducing environmental impact and pollution [159].

For example, as mentioned above, precision agriculture which uses IoT and BD, interconnected agriculture (referred to as the Internet of Farming) [160], and the crossanalysis of environmental, climatic and cultivation factors are all aimed at achieving greater efficiency in terms of saving time and resources as well as affecting product quality and increasing crop yields, thus increasing profitability and competitivity; however, they can have a big social impact as well, i.e., an improvement in working conditions and safety at work and an impact on sustainability: less waste, better use of environmentally harmful products, and optimized use of resources.

A more incisive "Common Agricultural Policy" is therefore needed in order to provide income support to farmers and to ensure the supply of high quality, safe, and affordable food to citizens while supporting society as a whole. Climate change, price volatility, political and economic uncertainty, rural displacement, and the growing importance of world trade are the challenges farmers face in a changing context that needs adequate support based on simple and clear rules in both the medium and long term, guiding the transition towards a more efficient and sustainable agricultural sector.

\section{The Case of Italy: Bridging an Infrastructure Gap with Digitization}

In this paragraph, Italy is proposed as a specific case for the potential application of the digital technologies mentioned above. Italy is a country where the use of digitization and new technologies in logistics, especially in the agri-food sector, could bring great improvements in efficiency and sustainability, for two main reasons.

First, for both its geographical conformation and for historical reasons Italy is characterized by a deep infrastructural and economic gap between the northern and southern 
regions. In contrast to the rest of Europe, in Italy there is still a strong North-South dualism [161], which can be seen in terms of infrastructure. It is therefore crucial for each region to lock in on growth markets with its exports. It is necessary to encourage better integration of Southern Italy into European and world growth markets and to increase the external accessibility of Southern Italy by reducing its European peripherality while at the same time increasing its global Mediterranean centrality.

Southern Italy should be efficiently connected with both the Northern part of the country and with the European rail networks, abandoning the idea of a "European quay" and focusing on ports and airports as factors of port-centric location and services with a global vocation. There are several critical points at the level of the Italian entrepreneurial system, particularly for the southern regions (exacerbated and sometimes made more evident by the pandemic crisis) which constitute a clear weakness in the ability to exploit the available potential. It is worth highlighting that:

- $\quad$ there was a sharp increase in business closures in 2020, amounting to 273,000;

- $\quad$ there was a $17 \%$ drop in new business start-ups compared to 2019;

- $\quad$ regarding the directors of businesses, between 2011 and 2019 there was an increase in the weight of the age group 70 and over of $6.4 \%$ nationally and $2.6 \%$ in the South, and at the same time a contraction in the weight of young entrepreneurs (aged under 29) of $1.6 \%$ nationally and $2.0 \%$ in the South (Source: Infocamere, Italy).

In Italy, and especially in the South, there is therefore, a need to invest in technologybased start-ups in order to be able to cope with the transformations and changes brought about by the serious epidemic crisis and by accelerated technological progress, which require new skills and abilities typical of the knowledge and digitalization era.

The strong development of new technology-based entrepreneurship taking place at the international level is well-documented by the fact that in the first quarter of 2021, the threshold of USD 100 billion of venture capital investments in start-ups was exceeded worldwide, with a 94\% increase compared to the same period in 2020 (Crunchbase data).

This gap reflects heavily on logistics and transport, especially when considering the need to move perishable goods produced in the south.

The digression above leads directly to another reason Italy is an interesting example for this paper. In fact, the second reason is linked to the industry on which the present analysis is focused, agri-food, which is strategic for the country; the development of the agribusiness sector is attaining ever-increasing importance [162]. This sector has traditionally played a key role for Italy, and the global emergency caused by the COVID-19 pandemic has raised widespread awareness of its core strategic value for the country [163], representing the most relevant Italian asset in 2020. Although not classified as "critical infrastructure", the agri-food supply chain, with all its companies, was called upon to guarantee the supply of essential goods throughout the pandemic crisis; in fact, it features inner and structural interdependencies with other "Critical Infrastructures", given that the supply and availability of foodstuffs is an essential system for maintaining the vital functions of the society as well as for national security; the disastrous consequences of social unrest caused by a possible race to hoard food are only one example [164].

The reality of the agri-food industry in Italy begins in the cultivation facilities and ends up on the shelves, providing about 3.8 million jobs and over $25 \%$ of GDP thanks to the activities of, among others, 740,000 farms, 70,000 food industries, over 330,000 restaurants, and 230,000 retail outlets (Source: Italian Coldiretti, 2021). These data immediately demonstrate the size and strategic importance of the sector.

The Italian agri-food chain has recorded continuous growth in exports [163], reaching a record figure of 44.6 billion euros in 2019, with almost two thirds of agri-food exports directed towards EU countries (where the main outlet is Germany), while outside of the EU the United States is the reference market for Italian food.

Agri-food logistics in the Italian market feature some strong specificities that are evident in all phases of the supply chain, and can be attributed to:

(1) The nature of the products (fresh, dried and frozen); 
(2) The complexity of upstream production and food processing chains;

(3) Growing globalization and internationalization of markets, both supply and outlets;

(4) The structure of sales channels (e-commerce, large-scale organized distribution).

In Italy, the offer of dedicated logistics services is evolving quickly, even if there are still major criticalities in the range of logistics services specifically offered to the agri-food sector. In fruit and vegetable processing, contrary to the general trend, road transport is the most widely used [165], with implications in terms of environmental sustainability. In fact, the fragmentation of road transport heavily affects primary transport, and the southto-north routes of the country in general. Alongside the technological drive and despite the delays and difficulties that persist in the Italian market, the themes of sustainability and intermodality are becoming more and more crucial for the government, and thus offer the cue for future progress in the agri-food logistics system even if the difficulty of aggregating the supply to create a critical mass for transport purposes remains the real crux of the southern Italian regions for both transports directed to the northern regions and for exports in general.

The efficiency of logistics services is hence very relevant for the creation and maintenance of competitive advantage for the Italian agri-food sector, and specifically for the fruit and vegetable sector, oil, milk and derivatives, and for all the products characterized by high perishability [166]. Particularly in the dairy supply chains, logistics play a decisive role in the procurement phase given the easy perishability of goods; this requires careful and efficient management of logistics [167] both upstream and downstream.

Each supply chain has its peculiarities which guide the choices relating to the management of logistics activities [168,169] linked to both individual products and processes, and it is equally clear that these choices are influenced by the weight that companies give to these activities for their competitiveness, especially on international markets. The optimization of the logistics chain and the right choice of contractual terms make a decisive contribution to the competitive positioning of a product on the market, and in a highly interconnected, globalized, and highly competitive world the quality and control of the supply chain are the factors that best define a company's competitive positioning.

Several considerations need to be outlined to make the agri-food chains more competitive in this country, and especially in Southern Italy.

Implementing some of the digital and enabling technologies mentioned in the first part of the present paper could lead to a strengthening of logistics platforms for the collection, processing, packaging and storage of agri-food products by promoting investments for the management of the cold chain through targeted interventions, eventually identifying and setting up agri-food logistics poles integrated with intermodal nodes [170-172].

The recovery of competitiveness of agri-food companies therefore greatly depends on the dissemination and the application of digitization culture to logistics, along with its associated advantages [173].

Through an enhancement of both connectivity and sustainability, i.e., through correct understanding of the advantages of integrated and coordinated logistics management, an increase in competitive advantage can be obtained in a country where it is not possible to totally bridge the infrastructural gap in a few years. In this way, new coordination mechanisms, organizational procedures, and strategies could be generated such as partnership with the operators involved along the supply chain, i.e., through the sharing of information and objectives through IoT, BD, DM and cloud paradigms. This raises the prospect of greater integration of Southern Italy into European and world markets through an increase in value added by logistical services to the goods produced in the southern regions, particularly in the agri-food sector.

Hence, in addition to large-scale infrastructure projects in the long term, it is important to consider technological development for existing infrastructures, i.e., both large-scale and small-scale projects aimed at improving existing links and exploiting the opportunities offered by digital technologies applied to transport and logistics to increase the speed and 
capacity of existing infrastructures, thereby enhancing economic returns in the short term by maximizing the efficiency of investments.

\section{Results, Discussion and Conclusions}

Logistics today is an integral part of a company's success [61]. Supply chain management is one of the key drivers on which organizations can focus in order to secure access to markets, increase their competitiveness through supply chain optimization, achieve economies of scale, and make strategic green choices to achieve full customer satisfaction.

\subsection{Digital Technologies Applied to Logistics: Value-Added and Sustainability}

While it is very important to discuss and evaluate the logistics endowment of the territory in terms of the road network, logistics activities in ports, freight villages, and logistics nodes [24], it is important as well to consider new digital technologies that could highly enhance the competitiveness of logistics through connectivity and improve sustainability by reducing negative externalities and optimizing resource.

For this reason, this paper has analyzed specific digital technologies and strategies which can, in various ways, be employed in logistics, with several positive effects in terms of managerial value creation and sustainability.

To better summarize some of these technologies and their potential applications within logistics, the following Table 1, while not exhaustive, gives an immediate glance at how they could positively affect both competitivity and sustainability.

Table 1. A selection of digital technologies along with their potential uses in logistics and consequent managerial and sustainability implications (authors' elaboration).

\begin{tabular}{|c|c|c|}
\hline Technology & Applications in Logistics & Managerial Sustainable Improvements \\
\hline $\begin{array}{c}\text { IoT } \\
{[103,121,142,153,160]}\end{array}$ & $\begin{array}{ll}\text { - } & \text { Just-in-time deliveries } \\
\text { - } & \text { Supply chain visibility and monitoring } \\
\text { - } & \text { Vehicle tracking } \\
\text { - } & \text { Eroduct lifecycle transparency } \\
\text { - } & \text { Automation of internal business processes } \\
\text { - } & \text { Fast, safe and efficient product delivery }\end{array}$ & $\begin{array}{ll}\text { - } & \text { Cost reduction } \\
\text { - } & \text { Reduced service times } \\
\text { - } & \text { Increased safety } \\
\text { - } & \text { Optimization of internal processes } \\
\text { - } & \text { Impry chain control } \\
\text { - } & \text { Improved reliability } \\
\end{array}$ \\
\hline $\begin{array}{c}\text { Big Data } \\
{[104,120,149-151,174]}\end{array}$ & $\begin{array}{l}\text { Segmentation of the supply chain and identification } \\
\text { of priorities) } \\
\text { - Integration of processes and organizational functions } \\
\text { Measurement of performance indicators and } \\
\text { - } \quad \begin{array}{l}\text { Preventive maintenance of vehicles, by monitoring } \\
\text { and analyzing the performance of vehicle operation }\end{array}\end{array}$ & $\begin{array}{ll}\text { - } & \text { Improved reliability } \\
\text { - } & \text { Cost reduction } \\
\text { - } & \text { Efficient material handling strategies } \\
\text { - } & \text { Improved operational lead times } \\
\text { - } & \text { Personalized customer care } \\
\text { - } & \text { Better organization of distribution } \\
& \text { flows and fleet routes }\end{array}$ \\
\hline $\begin{array}{l}\text { Digital Twins } \\
{[131,175]}\end{array}$ & $\begin{array}{ll}\text { - } & \text { Container fleet management Shipment monitoring } \\
\text { - } & \text { Design of entire logistics systems } \\
\text { - } & \text { Packaging } \\
\text { - } & \text { Automatic Warehouse Studio (AWS) }\end{array}$ & $\begin{array}{l}\text { Safety (e.g., of the warehouse } \\
\text { structure) } \\
\text { - } \quad \text { Evaluation of the efficiency of logistics } \\
\text { processes } \\
\text { Evaluation of changes in logistics } \\
\text { planning for a structure } \\
\text { - Smoother and more efficient } \\
\text { implementation of the warehouse } \\
\text { management system (WMS) } \\
\text { Identification of errors and } \\
\text { inefficiencies }\end{array}$ \\
\hline
\end{tabular}


Table 1. Cont.

\begin{tabular}{|c|c|c|}
\hline Technology & Applications in Logistics & Managerial Sustainable Improvements \\
\hline $\begin{array}{c}\text { Blockchain } \\
{[89,121,131,176]}\end{array}$ & $\begin{array}{l}\text { - } \quad \text { Management of transport documents, goods } \\
\text { - } \quad \text { Delivery monitoring } \\
\text { - } \quad \text { Geolocation } \\
\text { - } \quad \text { Delivery statistics updated in real-time }\end{array}$ & $\begin{array}{ll}\text { - } & \text { Greater data transparency } \\
\text { - } & \text { Smart contract } \\
\text { - } & \text { Secure data (encryption) } \\
\text { - } & \text { Clarity in asset management Real-time } \\
& \text { asset monitoring }\end{array}$ \\
\hline $\begin{array}{c}\text { Vision Picking } \\
{[96,177]}\end{array}$ & $\begin{array}{ll}\text { - } & \text { Smart glasses } \\
\text { - } & \text { Geolocation } \\
\text { - } & \text { Picking execution }\end{array}$ & $\begin{array}{ll}\text { - } & \text { Increased warehouse flexibility } \\
\text { - } & \text { Security } \\
\text { - } & \text { Cost Reduction } \\
\text { More efficient operations }\end{array}$ \\
\hline $\begin{array}{l}\text { Virtual Reality (VR) } \\
\& \\
\text { Augmented Reality } \\
\text { (VR) } \\
{[96,178-180]}\end{array}$ & $\begin{array}{ll}- & \text { User interface } \\
\text { - } & \text { Real-time remote interaction } \\
\text { On-the-job training of employees }\end{array}$ & $\begin{array}{ll}\text { - } & \text { Increased performance of production } \\
\text { - } & \text { processes } \\
\text { - } & \text { Errors reduction } \\
\text { - } & \text { Increased efficiency in order processing } \\
\text { - } & \text { Optimization of the processes involved } \\
\text { in the supply chain }\end{array}$ \\
\hline $\begin{array}{l}\text { Cloud Computing } \\
{[40,80,113,114,181]}\end{array}$ & $\begin{array}{ll}\text { - } & \text { System-as-a-Service (SaaS) } \\
\text { - } & \text { Desktop-as-a-Service (DaaS) } \\
\text { - } & \text { Hardware-as-a-Service (HaaS) }\end{array}$ & $\begin{array}{ll}\text { - } & \text { Outsourcing of organizational and } \\
\text { - } & \text { Llanning activities } \\
\text { - } & \text { Reduction of hardware, software and } \\
& \text { license costs } \\
\text { - } & \text { Archives accessible at any time } \\
\text { (portability) } \\
\text { - } \quad \text { Increased archive potential Flexibility } \\
\text { Interoperability }\end{array}$ \\
\hline $\begin{array}{l}\text { Unmanned Aerial } \\
\text { Vehicles } \\
\text { (UAV)-Drones } \\
\text { [182-185] }\end{array}$ & $\begin{array}{ll}\text { - } & \text { Last mile deliveries } \\
\text { - } & \text { Semi-automated physical inventory } \\
\text { - } & \text { Physical distribution of goods in city centers } \\
\text { - } & \text { Precision farming } \\
\text { - } & \text { Crop monitoring } \\
\text { - } & \text { Drafting of vigour maps }\end{array}$ & $\begin{array}{ll}\text { - } & \text { Cost reduction } \\
\text { - } & \text { Increased efficiency and effectiveness } \\
\text { - } & \text { of operations } \\
\text { - } & \text { Impronironental sustainability } \\
\text { - } & \text { Process improvement } \\
\text { - } & \text { Improved inventory operations } \\
\text { - } & \text { Simplified facility management and } \\
& \text { goods security } \\
\text { - } & \text { Strategic asset management } \\
\text { - } & \text { Activation of extra security controls }\end{array}$ \\
\hline
\end{tabular}

\subsection{Digitization and New Technologies in the Agri-Food Sector}

The evolutionary processes underway, the new technologies mentioned in this article, and the new requirements in terms of organization of production and the logistics chain all have a profound effect on the functions and roles of the transport actors in all their various forms, inducing companies, and in particular agricultural companies, to profoundly change their logistics concepts.

As noted, agri-food is an industry where logistics plays a crucial and strategic role; hence, companies and countries can gain a competitive advantage by investing in digital technologies. In addition, the positive effects lie in not only economic value, but an increase in sustainability as well, through a reduction of waste and negative externalities. In Figure 1, a typical agri-food process is provided along with a specification of some digital 
technologies that could be used in the various phases. This figure is based on data from several references [89,96,146,149,164,173,179,182,185].

\section{AGRI-FOOD SUPPLY CHAIN and DIGITAL TECHNOLOGIES}

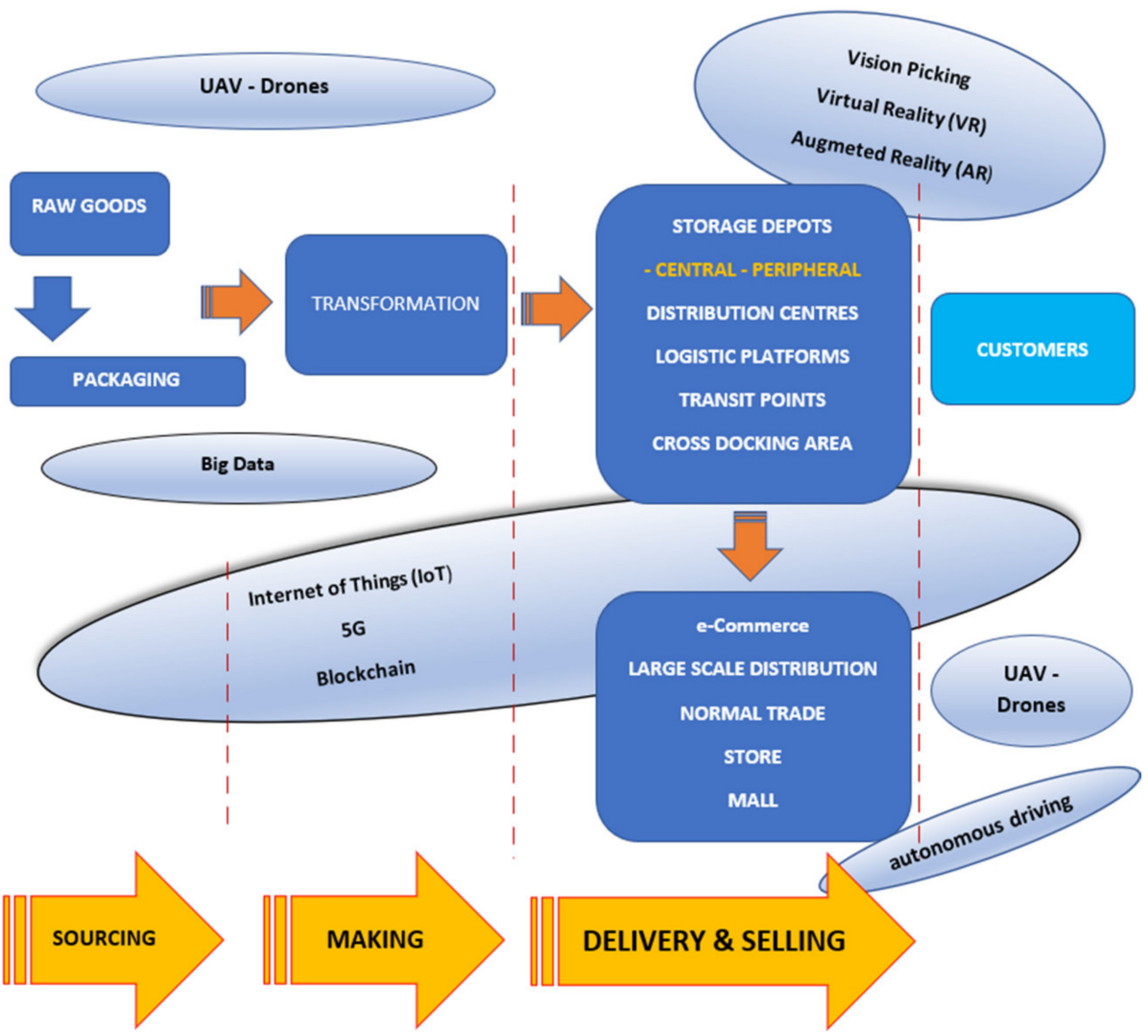

Figure 1. A typical agri-food supply chain with digital technologies applied to various phases (authors' elaboration).

Regarding the specific area of sustainability, the accurate measurement and potential containment of GHG emissions from supply chain movement and agri-food logistics operations could accelerate the reduction of negative environmental impacts of transport, and should therefore become a priority for both companies and governments. Digital technologies, as indicated in the paper, can further support such specific operations as cargo consolidation and collaboration between all parties involved in the agri-food supply chain through improved information sharing, reducing operational delays and avoidable trips so that economic growth and environmental sustainability can go together in the long-term.

\subsection{Managerial Implications and the Case of Italy}

From the literature review, a clear strategic direction emerges for both company managers and country governments. In particular, it emerges that logistics is a fundamental resource that brings value and competitive advantage to companies and countries; the development trajectories for improving this resource are those of connectivity and sustainability, and these two objectives are closely interconnected and can benefit greatly from the use of new technologies and the digitization of processes, procedures, and documents.

It is therefore of paramount importance for companies and governments to seize the opportunities offered by technology and invest heavily in digitization in the logistics and infrastructure sector in order to increase competitiveness and sustainability. 
The strategic implications above can be transposed to the agri-food sector, in which logistics plays a fundamental role both because of the specific nature of the products handled (usually very delicate and perishable) and the need to operate over long distances, often in countries where the infrastructure is not efficient. In this specific context, the use of digital technologies is so important that it has given rise to the specific term AgriTech. Entrepreneurs in this sector must therefore look to improving the quality of their products by investing in technological solutions that can bring the producer closer to the consumer and increase the sustainability of the underlying processes.

Italy represents an exemplary case for both aspects mentioned above. It is characterized by a deep and lasting gap between the northern and southern regions, both from an economic/managerial and an infrastructural point of view. Moreover, the agri-food sector is the most important for the country's economy, accounting for about 25\% of GDP. While the importance of infrastructure improvement enabling better and more efficient physical connectivity between north and south is fundamental in the medium-long term, investment in enabling technologies that make it possible to overcome obstacles and foster connectivity while improving sustainability is essential for the competitiveness of businesses and the country system as a whole in the short and medium terms. Despite the gap referred to above, it is worth noting that in the national context, southern Italy seems to be the area with the best opportunities for investment in new businesses, as about $25 \%$ of innovative start-ups and about $40 \%$ of innovative SMEs are concentrated in this region. This would seem to be an excellent premise for the possibility of using high technology and digitalization in the sectors of logistics and agri-food which are so fundamental for the country and even more so for the southern regions.

Author Contributions: Conceptualization, M.R. and A.Z.; methodology, M.R.; validation, M.R. and A.Z.; formal analysis, M.R. and A.Z.; investigation, M.R.; resources, M.R. and A.Z.; writing-original draft preparation, M.R. and A.Z.; writing-review and editing, M.R. and A.Z.; supervision, M.R. All authors have read and agreed to the published version of the manuscript.

Funding: This research received no external funding.

Institutional Review Board Statement: Not applicable.

Informed Consent Statement: Not applicable.

Data Availability Statement: Not applicable.

Conflicts of Interest: The authors declare no conflict of interest.

\section{References}

1. Kovács, G.; Kot, S. New Logistics and Production Trends as the Effect of Global Economy Changes. Pol. J. Manag. Stud. 2016, 14, 115-125. [CrossRef]

2. Giallombardo, G.; Guerriero, F.; Miglionico, G. Profit Maximization via Capacity Control for Distribution Logistics Problems. arXiv 2020, arXiv:2008.03216.

3. Bronshtein, E.M.; Gindullin, R.V. Exact Solutions of Some Optimization Problems of Transport Logistics. Math. Models Comput. Simul. 2014, 6, 332-336. [CrossRef]

4. Roh, S.; Thai, V.V.; Wong, Y.D. Towards Sustainable ASEAN Port Development: Challenges and Opportunities for Vietnamese Ports. Asian J. Shipp. Logist. 2016, 32, 107-118. [CrossRef]

5. Kuan, S.H.; Ghorbani, Y.; Chieng, S. Narrowing the Gap between Local Standards and Global Best Practices in Bauxite Mining: A Case Study in Malaysia. Resour. Policy 2020, 66, 101636. [CrossRef]

6. Murray, M.M. Cargo on the Move: Options for Infrastructure and Air Quality Improvements at the San Pedro Bay Ports. Master's Thesis, California State University, Sacramento, CA, USA, 2012.

7. Merenkov, A. Digital Economy: Transport Management and Intelligent Transportation Systems. E-Management 2018, 1, 12-18. [CrossRef]

8. Bobrova, V.V.; Berezhnaya, L.Y. Digitization of the Transport Industry in Russia: Problems and Prospects. In Proceedings of the 1st International Scientific Conference "Modern Management Trends and the Digital Economy: From Regional Development to Global Economic Growth" (MTDE), Institute of International Relations, Yekaterinburg, Russia, 14-15 April 2019 ; pp. 1-4.

9. Antonov, A.A. Digitization of Processes of Sea Freight Transportation. 2020. Available online: https://er.nau.edu.ua/handle/ NAU / 49875?locale=en (accessed on 25 November 2021). 
10. Anwar, M.; Henesey, L.; Casalicchio, E. Digitalization in Container Terminal Logistics: A Literature Review. In Proceedings of the 27th Annual Conference of International Association of Maritime Economists, Athens, Greece, 25-28 June 2019; pp. 1-25.

11. Fruth, M.; Teuteberg, F. Digitization in Maritime Logistics-What Is There and What Is Missing? Cogent Bus. Manag. 2017, 4, 1411066. [CrossRef]

12. Remondino, M. Information Technology in Healthcare: HHC-MOTES, a Novel Set of Metrics to Analyse IT Sustainability in Different Areas. Sustainability 2018, 10, 2721. [CrossRef]

13. Kahn, K.B.; Mentzer, J.T. Logistics and Interdepartmental Integration. Int. J. Phys. Distrib. Logist. Manag. 1996, 6, 6-14. [CrossRef]

14. Shibasaki, R.; Watanabe, D.; Kawasaki, T. Global and International Logistics. Sustainability 2021, 13, 5610. [CrossRef]

15. De Andres Gonzalez, O.; Koivisto, H.; Mustonen, J.M.; Keinänen-Toivola, M.M. Digitalization in Just-In-Time Approach as a Sustainable Solution for Maritime Logistics in the Baltic Sea Region. Sustainability 2021, 13, 1173. [CrossRef]

16. Parfenov, A.; Shamina, L.; Niu, J.; Yadykin, V. Transformation of Distribution Logistics Management in the Digitalization of the Economy. J. Open Innov. Technol. Mark. Complex. 2021, 7, 58. [CrossRef]

17. Todorovic, V.; Maslaric, M.; Bojic, S.; Jokic, M.; Mircetic, D.; Nikolicic, S. Solutions for More Sustainable Distribution in the Short Food Supply Chains. Sustainability 2018, 10, 3481. [CrossRef]

18. Pernestål, A.; Engholm, A.; Bemler, M.; Gidofalvi, G. How Will Digitalization Change Road Freight Transport? Scenarios Tested in Sweden. Sustainability 2021, 13, 304. [CrossRef]

19. Omta, S.W.F.; Folstar, P. Integration of Innovation in the Corporate Strategy of Agri-Food Companies. Innov. Agri-Food Syst. 2005, 1, 223-246.

20. Paciarotti, C.; Torregiani, F. The Logistics of the Short Food Supply Chain: A Literature Review. Sustain. Prod. Consum. 2021, 26, 428-442. [CrossRef]

21. Majewski, E.; Komerska, A.; Kwiatkowski, J.; Malak-Rawlikowska, A.; Wąs, A.; Sulewski, P.; Gołaś, M.; Pogodzińska, K.; Lecoeur, J.-L.; Tocco, B. Are Short Food Supply Chains More Environmentally Sustainable than Long Chains? A Life Cycle Assessment (LCA) of the Eco-Efficiency of Food Chains in Selected EU Countries. Energies 2020, 13, 4853. [CrossRef]

22. Saitone, T.L.; Sexton, R.J. Agri-Food Supply Chain: Evolution and Performance with Conflicting Consumer and Societal Demands. Eur. Rev. Agric. Econ. 2017, 44, 634-657. [CrossRef]

23. Gandino, F.; Montrucchio, B.; Rebaudengo, M.; Sanchez, E.R. Analysis of an RFID-Based Information System for Tracking and Tracing in an Agri-Food Chain. In Proceedings of the 2007 1st Annual RFID Eurasia, Istanbul, Turkey, 5-6 September 2007; IEEE: Piscataway, NJ, USA, 2007; pp. 1-6.

24. Carlucci, F.; Cirà, A.; Forte, E.; Siviero, L. Infrastructure and Logistics Divide: Regional Comparisons between North Eastern \& Southern Italy. Technol. Econ. Dev. Econ. 2017, 23, 243-269.

25. Ivanov, D.; Tsipoulanidis, A.; Schönberger, J. Global Supply Chain and Operations Management. Decis.-Oriented Introd. Creat. Value 2017, 2, 203-245.

26. Chen, H.-M.; Kazman, R.; Garbajosa, J.; Gonzalez, E. Toward Big Data Value Engineering for Innovation. In Proceedings of the 2nd International Workshop on BIG Data Software Engineering, Austin, TX, USA, 16 May 2016; ACM: New York, NY, USA, 2016; pp. 44-50.

27. Patil, M.A.L.; Rane, B.V. Analyzing the Importance of Logistics in Supply Chain Management. PalArchs J. Archaeol. Egypt/Egyptol. 2021, 18, 2196-2202.

28. Mir, A.; Lazaar, S.; Balambo, M.A. The Logistics Service Provider as an Integrator of Supply Chain. Evidences from an Emerging Market. Rev. Eur. D'économie Et Manag. Des Serv. 2021, 2021, 69-91.

29. Sahay, B.S. Supply Chain Collaboration: The Key to Value Creation. Work Study 2003, 52, 76-83. [CrossRef]

30. Indriastiwi, F.; Hadiwardoyo, S.P. Port Connectivity Model in The Perspective of Multimodal Transport: A Conceptual Framework. In Proceedings of the IOP Conference Series: Materials Science and Engineering, Sanya, China, 12-14 November 2021; IOP Publishing: Bristol, UK, 2021; Volume 1052, p. 012008.

31. Yang, Y.-C.; Chen, S.-L. Determinants of Global Logistics Hub Ports: Comparison of the Port Development Policies of Taiwan, Korea, and Japan. Transp. Policy 2016, 45, 179-189. [CrossRef]

32. Berli, J.; Bunel, M.; Ducruet, C. Sea-Land Interdependence in the Global Maritime Network: The Case of Australian Port Cities. Netw. Spat. Econ. 2018, 18, 447-471. [CrossRef]

33. Bensassi, S.; Márquez-Ramos, L.; Martínez-Zarzoso, I.; Suárez-Burguet, C. Relationship between Logistics Infrastructure and Trade: Evidence from Spanish Regional Exports. Transp. Res. Part A Policy Pract. 2015, 72, 47-61. [CrossRef]

34. Nam, H.-S.; Song, D.-W. Defining Maritime Logistics Hub and Its Implication for Container Port. Marit. Policy Manag. 2011, 38, 269-292. [CrossRef]

35. Rimienè, K.; Grundey, D. Logistics Centre Concept through Evolution and Definition. Eng. Econ. 2007, 54, 87-95.

36. Porter, M.E.; Kramer, M.R. Creating Shared Value. In Managing Sustainable Business; Springer: Berlin/Heidelberg, Germany, 2019; pp. 323-346.

37. Dolan, C.; Humphrey, J. Governance and Trade in Fresh Vegetables: The Impact of UK Supermarkets on the African Horticulture Industry. J. Dev. Stud. 2000, 37, 147-176. [CrossRef]

38. Roche, I.C.; Barbolla, J.O.; Guillén, M.J.Y. Price Differences in Consumer Goods in Retail Markets: Spatial and Vertical Competition Analysis. J. Mark. Channels 2006, 13, 49-67. [CrossRef] 
39. Lehmacher, W. Digitizing and Automating Processes in Logistics. In Disrupting Logistics; Springer: Berlin/Heidelberg, Germany, 2021; pp. 9-27.

40. Dehmer, J.; Niemann, J. Value Chain Management through Cloud-Based Platforms. Procedia-Soc. Behav. Sci. 2018, 238, 177-181. [CrossRef]

41. Kiel, D.; Müller, J.M.; Arnold, C.; Voigt, K.-I. Sustainable Industrial Value Creation: Benefits and Challenges of Industry 4.0. In Digital Disruptive Innovation; World Scientific: Singapore, 2020; pp. 231-270.

42. Avetisyan, M.; Hertel, T.; Sampson, G. Is Local Food More Environmentally Friendly? The GHG Emissions Impacts of Consuming Imported versus Domestically Produced Food. Environ. Resour. Econ. 2014, 58, 415-462. [CrossRef]

43. Memari, A.; Rahim, A.R.A.; Ahmad, R.B. An Integrated Production-Distribution Planning in Green Supply Chain: A MultiObjective Evolutionary Approach. Procedia Cirp 2015, 26, 700-705. [CrossRef]

44. McKinnon, A. Decarbonizing Logistics: Distributing Goods in a Low Carbon World; Kogan Page Publishers: London, UK, 2018.

45. Hesse, M.; Rodrigue, J.-P. The Transport Geography of Logistics and Freight Distribution. J. Transp. Geogr. 2004, 12, 171-184. [CrossRef]

46. Avram, D.O.; Kühne, S. Implementing Responsible Business Behavior from a Strategic Management Perspective: Developing a Framework for Austrian SMEs. J. Bus. Ethics 2008, 82, 463-475. [CrossRef]

47. Carayannis, E.G.; Sindakis, S.; Walter, C. Business Model Innovation as Lever of Organizational Sustainability. J. Technol. Transf. 2015, 40, 85-104. [CrossRef]

48. Elkington, J. Towards the Sustainable Corporation: Win-Win-Win Business Strategies for Sustainable Development. Calif. Manag. Rev. 1994, 36, 90-100. [CrossRef]

49. Piecyk, M.I.; Björklund, M. Logistics Service Providers and Corporate Social Responsibility: Sustainability Reporting in the Logistics Industry. Int. J. Phys. Distrib. Logist. Manag. 2015, 45, 459-485. [CrossRef]

50. Pawlik, T.; Gaffron, P.; Drewes, P.A. Corporate Social Responsibility in Maritime Logistics. In Maritime Logistics; Emerald Group Publishing Limited: Bingley, UK, 2012.

51. Notteboom, T.; Rodrigue, J.-P. Re-Assessing Port-Hinterland Relationships in the Context of Global Commodity Chains. In Ports, Cities, and Global Supply Chains; Routledge: London, UK, 2017; pp. 67-82.

52. Rodrigue, J.-P.; Notteboom, T. The Terminalization of Supply Chains: Reassessing the Role of Terminals in Port/Hinterland Logistical Relationships. Marit. Policy Manag. 2009, 36, 165-183. [CrossRef]

53. Emmett, S.; Sood, V. Green Supply Chains: An Action Manifesto; John Wiley \& Sons: Hoboken, NJ, USA, 2010.

54. Maliza Delima, K.Z. Environmental Ethical Commitment of the Business Corporations in Malaysia/Maliza Delima Binti Kamarul Zaman. Ph.D. Thesis, Universiti Malaya, Kuala Lumpur, Malaysia, 2011.

55. Xie, Y.; Breen, L. Greening Community Pharmaceutical Supply Chain in UK: A Cross Boundary Approach. Supply Chain Manag. Int. J. 2012, 17, 40-53. [CrossRef]

56. Bouklata, A.; Bensfia, C. Digitalization of Port Passage Procedures: Focus on the Transit Time of Goods. In Proceedings of the 2020 IEEE 13th International Colloquium of Logistics and Supply Chain Management (LOGISTIQUA), Fez, Morocco, 2-4 December 2020; IEEE: Piscataway, NJ, USA, 2020; pp. 1-6.

57. Errico, F.; Corallo, A.; Barriera, R.; Prato, M. Dematerialization, Archiving and Recovery of Documents: A Proposed Tool Based on a Semantic Classifier and a Semantic Search Engine. In Proceedings of the 2020 9th International Conference on Industrial Technology and Management (ICITM), Oxford, UK, 11-13 February 2020; IEEE: Piscataway, NJ, USA, 2020 ; pp. $297-301$.

58. Dörr, S. Watch It! Thinking Digitalization and Sustainability Together. In Corporate Digital Responsibility; Springer: Berlin/Heidelberg, Germany, 2021; pp. 53-83.

59. Colombo, B.; Gaiardelli, P.; Dotti, S.; Boffelli, A. Business Models in Circular Economy: A Systematic Literature Review. In Proceedings of the IFIP International Conference on Advances in Production Management Systems, Nantes, France, 5-9 September 2021; Springer: Berlin/Heidelberg, Germany, 2021; pp. 386-393.

60. David, B.G.; Trautrims, A.; Wong, C.Y. Sustainable Logistics and Supply Chain Management 2021. Available online: http:/ / dspace.vnbrims.org:13000/jspui/bitstream/123456789/4493/1/Sustainable\%20Logistics\%20and\%20Supply\%20 Chain\%20Management.pdf (accessed on 25 November 2021).

61. Ntuchu, R.G. Efficient Logistics Operation in a Supply Chain. 2019. Available online: https://www.theseus.fi/bitstream/handle/ 10024/264784/Ntuchu_RexdonaldGweko.pdf?sequence=2\&isAllowed=y (accessed on 25 November 2021).

62. Matopoulos, A.; Vlachopoulou, M.; Manthou, V.; Manos, B. A Conceptual Framework for Supply Chain Collaboration: Empirical Evidence from the Agri-Food Industry. Supply Chain Manag. Int. J. 2007, 12, 177-186. [CrossRef]

63. Solarte-Montufar, J.G.; Zartha-Sossa, J.W.; Osorio-Mora, O. Open Innovation in the Agri-Food Sector: Perspectives from a Systematic Literature Review and a Structured Survey in MSMEs. J. Open Innov. Technol. Mark. Complex. 2021, 7, 161. [CrossRef]

64. Jałowiecki, P. Dupont Analysis of Polish Agri-Food Industry Selected Sectors-Logistic Aspects. Res. Logist. Prod. 2018, 8, 217-227.

65. Raźniewska, M. Meeting the Challenges of Food Sector Using Supplier Relationship Management. Available online: https:/ / www.researchgate.net/profile/Marta-Razniewska/publication/336929843_Meeting_the_Challenges_of_Food_ Sector_using_Supplier_Relationship_Management/links/60381a61299bf1cc26efa7d0/Meeting-the-Challenges-of-Food-Sectorusing-Supplier-Relationship-Management.pdf (accessed on 25 November 2021).

66. Fang, Y.; Jiang, Y.; Sun, L.; Han, X. Design of Green Cold Chain Networks for Imported Fresh Agri-Products in Belt and Road Development. Sustainability 2018, 10, 1572. [CrossRef] 
67. Gössling, S. ICT and Transport Behavior: A Conceptual Review. Int. J. Sustain. Transp. 2018, 12, 153-164. [CrossRef]

68. Ülkü, M.A.; Engau, A. Sustainable Supply Chain Analytics. Ind. Innov. Infrastruct. 2021, 1123-1134. [CrossRef]

69. Nikitas, A.; Michalakopoulou, K.; Njoya, E.T.; Karampatzakis, D. Artificial Intelligence, Transport and the Smart City: Definitions and Dimensions of a New Mobility Era. Sustainability 2020, 12, 2789. [CrossRef]

70. Leurent, F.; Haxaire, O.; Lesteven, G. Smart Mobility: A Landscape Under Development. In Eco-Design of Buildings and Infrastructure; CRC Press: Boca Raton, FL, USA, 2020; pp. 449-496.

71. Xu, Z.; Li, J.; Zhao, X.; Li, L.; Wang, Z.; Tong, X.; Tian, B.; Hou, J.; Wang, G.; Zhang, Q. A Review on Intelligent Road and Its Related Key Technologies. China J. Highw. Transp. 2019, 32, 1-24.

72. Fiedler, R.; Bosse, C.; Gehlken, D.; Brümmerstedt, K.; Burmeister, H.S. Autonomous Vehicles' Impact on Port Infrastructure Requirements; Fraunhofer-Center für Maritime Logistik und Dienstleistungen CML: Hamburg, Germany, 2019. Available online: https: / / safety4sea.com/wp-content/uploads/2019/06/IAPHPort-of-Hamburg-Autonomous-vehicles-impact-on-portinfrastructure-requirements-2019_06.pdf (accessed on 25 November 2021).

73. Novikova, O. The Sharing Economy and the Future of Personal Mobility: New Models Based on Car Sharing. Technol. Innov. Manag. Rev. 2017, 7, 27-31. [CrossRef]

74. Wong, Y.Z.; Hensher, D.A.; Mulley, C. Mobility as a Service (MaaS): Charting a Future Context. Transp. Res. Part A Policy Pract. 2020, 131, 5-19. [CrossRef]

75. Chen, C.; Wang, J.; Xu, Q.; Wang, J.; Li, K. Mixed Platoon Control of Automated and Human-Driven Vehicles at a Signalized Intersection: Dynamical Analysis and Optimal Control. Transp. Res. Part C Emerg. Technol. 2021, 127, 103138. [CrossRef]

76. Varaldo, R. La Nuova Partita Dell'innovazione: Il Futuro Dell'industria in Italia; Saggi Il Mulino: Bologna, Italy, 2014; ISBN 978-88-15-25375-0.

77. Ye, L.; Yamamoto, T. Modeling Connected and Autonomous Vehicles in Heterogeneous Traffic Flow. Phys. A Stat. Mech. Its Appl. 2018, 490, 269-277. [CrossRef]

78. Flämig, H. Autonomous Vehicles and Autonomous Driving in Freight Transport. In Autonomous Driving; Springer: Berlin/Heidelberg, Germany, 2016; pp. 365-385.

79. Nie, J.; Zhang, J.; Ding, W.; Wan, X.; Chen, X.; Ran, B. Decentralized Cooperative Lane-Changing Decision-Making for Connected Autonomous Vehicles. IEEE Access 2016, 4, 9413-9420. [CrossRef]

80. Shengdong, M.; Zhengxian, X.; Yixiang, T. Intelligent Traffic Control System Based on Cloud Computing and Big Data Mining IEEE Trans. Ind. Inform. 2019, 15, 6583-6592. [CrossRef]

81. Givoni, M.; Perl, A. Rethinking Transport Infrastructure Planning to Extend Its Value over Time. J. Plan. Educ. Res. 2020, 40, 82-91. [CrossRef]

82. Di Carlo, F.; Mazzuto, G.; Bevilacqua, M.; Ciarapica, F.E. Retrofitting a Process Plant in an Industry 4.0 Perspective for Improving Safety and Maintenance Performance. Sustainability 2021, 13, 646. [CrossRef]

83. Bahers, J.-B.; Tanguy, A.; Pincetl, S. Metabolic Relationships between Cities and Hinterland: A Political-Industrial Ecology of Energy Metabolism of Saint-Nazaire Metropolitan and Port Area (France). Ecol. Econ. 2020, 167, 106447. [CrossRef]

84. Jugović, A.; Sirotić, M.; Peronja, I. Sustainable Development of Port Cities from the Perspective of Transition Management. Trans. Marit. Sci. 2021, 10, 466-476. [CrossRef]

85. Serry, A.; Loubet, L. Developing the City, Developing the Port: Comparison of the Governance in Medium-Size Port-Cities in Europe. TransNav Int. J. Mar. Navig. Saf. Sea Transp. 2019, 13, 607-614. [CrossRef]

86. Alicke, K.; Rexhausen, D.; Seyfert, A. Supply Chain 4.0 in Consumer Goods; Mckinsey Co: New York, NY, 2017; pp. 1-11. Available online: https://www.mckinsey.com/ \{\}/media/McKinsey/Industries/Consumer\%20Packaged\%20Goods/Our\%20 Insights/Supply\%20Chain\%204\%200\%20in\%20consumer\%20goods/Supply-Chain-4-0-in-consumer-goods-vf.pdf (accessed on 25 November 2021).

87. Wang, J.; Lim, M.K.; Zhan, Y.; Wang, X. An Intelligent Logistics Service System for Enhancing Dispatching Operations in an IoT Environment. Transp. Res. Part E: Logist. Transp. Rev. 2020, 135, 101886. [CrossRef]

88. Heilig, L.; Lalla-Ruiz, E.; Voß, S. Digital Transformation in Maritime Ports: Analysis and a Game Theoretic Framework. Netnomics Econ. Res. Electron. Netw. 2017, 18, 227-254. [CrossRef]

89. Dobrovnik, M.; Herold, D.M.; Fürst, E.; Kummer, S. Blockchain for and in Logistics: What to Adopt and Where to Start. Logistics 2018, 2, 18. [CrossRef]

90. Ranieri, L.; Digiesi, S.; Silvestri, B.; Roccotelli, M. A Review of Last Mile Logistics Innovations in an Externalities Cost Reduction Vision. Sustainability 2018, 10, 782. [CrossRef]

91. Wong, Y.Z.; Hensher, D.A.; Mulley, C. Emerging Transport Technologies and the Modal Efficiency Framework: A Case for Mobility as a Service (MaaS). 2018. Available online: https://ses.library.usyd.edu.au/handle/2123/19100 (accessed on 25 November 2021).

92. Remondino, M.; Cappellini, A. Minority Game with Communication of Statements and Memory Analysis: A Multi Agent Based Model. Int. J. Simul. Syst. Sci. Technol. 2005, 6, 42-53.

93. Anderluh, A.; Nolz, P.C.; Hemmelmayr, V.C.; Crainic, T.G. Multi-Objective Optimization of a Two-Echelon Vehicle Routing Problem with Vehicle Synchronization and 'Grey Zone'Customers Arising in Urban Logistics. Eur. J. Oper. Res. 2021, 289, 940-958. [CrossRef] 
94. Bac, U.; Erdem, M. Optimization of Electric Vehicle Recharge Schedule and Routing Problem with Time Windows and Partial Recharge: A Comparative Study for an Urban Logistics Fleet. Sustain. Cities Soc. 2021, 70, 102883. [CrossRef]

95. Chen, Y.; Huang, Z.; Ai, H.; Guo, X.; Luo, F. The Impact of GIS/GPS Network Information Systems on the Logistics Distribution Cost of Tobacco Enterprises. Transp. Res. Part E Logist. Transp. Rev. 2021, 149, 102299. [CrossRef]

96. Remondino, M. Augmented Reality in Logistics: Qualitative Analysis for a Managerial Perspective. Int. J. Logist. Syst. Manag. 2020, 35, 1. [CrossRef]

97. Kraft, P.; Helm, R.; Dowling, M. New Business Models with Industrie 4.0 in the German Mittelstand. Int. J. Technol. Policy Manag. 2021, 21, 47-68. [CrossRef]

98. Rodrigue, J.-P.; Slack, B.; Comtois, C. Green Logistics. In Handbook of Logistics and Supply-Chain Management; Emerald Group Publishing Limited: Bingley, UK, 2017.

99. Botti, A.; Monda, A.; Pellicano, M.; Torre, C. The Re-Conceptualization of the Port Supply Chain as a Smart Port Service System: The Case of the Port of Salerno. Systems 2017, 5, 35. [CrossRef]

100. Chen, J.; Huang, T.; Xie, X.; Lee, P.T.-W.; Hua, C. Constructing Governance Framework of a Green and Smart Port. J. Mar. Sci. Eng. 2019, 7, 83. [CrossRef]

101. Zis, T.P. Green Ports. In Sustainable Shipping; Springer: Berlin/Heidelberg, Germany, 2019; pp. 407-432.

102. Klumpp, M. Automation and Artificial Intelligence in Business Logistics Systems: Human Reactions and Collaboration Requirements. Int. J. Logist. Res. Appl. 2018, 21, 224-242. [CrossRef]

103. Haddud, A.; DeSouza, A.; Khare, A.; Lee, H. Examining Potential Benefits and Challenges Associated with the Internet of Things Integration in Supply Chains. J. Manuf. Technol. Manag. 2017, 28, 1055-1085. [CrossRef]

104. Govindan, K.; Cheng, T.E.; Mishra, N.; Shukla, N. Big Data Analytics and Application for Logistics and Supply Chain Management. Transp. Res. Part E Logist. Transp. Rev. 2018, 114, 343-349. [CrossRef]

105. Lee, P.T.-W.; Kwon, O.K.; Ruan, X. Sustainability Challenges in Maritime Transport and Logistics Industry and Its Way Ahead. Sustainability 2019, 11, 1331. [CrossRef]

106. Lipych, L.; Bortnik, S.; Tovsteniuk, O.; Kchilycha, O.; Kushnir, M. Prospects for the Introduction of Innovations by Agricultural Enterprises in Ukraine. Probl. Perspect. Manag. 2017, 15, 53-63. [CrossRef]

107. Arvis, J.-F.; Ojala, L.; Wiederer, C.; Shepherd, B.; Raj, A.; Dairabayeva, K.; Kiiski, T. Connecting to Compete 2018; World Bank: Washington, DC, USA, 2018.

108. Agrawal, M.; Eloot, K.; Mancini, M.; Patel, A. Industry 4.0: Reimagining Manufacturing Operations after COVID-19; McKinsey \& Company: New York, NY, USA, 2020. Available online: https://www.mckinsey.com/business-functions/operations/ourinsights/industry-40-reimagining-manufacturing-operations-after-covid-19 (accessed on 20 August 2020).

109. Mohamed, M. Challenges and Benefits of Industry 4.0: An Overview. Int. J. Supply Oper. Manag. 2018, 5, $256-265$.

110. Bastas, A.; Liyanage, K. Setting a Framework for Organisational Sustainable Development. Sustain. Prod. Consum. 2019, 20, 207-229. [CrossRef]

111. Parida, V.; Sjödin, D.; Reim, W. Reviewing Literature on Digitalization, Business Model Innovation, and Sustainable Industry: Past Achievements and Future Promises. Sustainability 2019, 11, 391. [CrossRef]

112. Ordieres-Meré, J.; Prieto Remon, T.; Rubio, J. Digitalization: An Opportunity for Contributing to Sustainability from Knowledge Creation. Sustainability 2020, 12, 1460. [CrossRef]

113. Manuel Maqueira, J.; Moyano-Fuentes, J.; Bruque, S. Drivers and Consequences of an Innovative Technology Assimilation in the Supply Chain: Cloud Computing and Supply Chain Integration. Int. J. Prod. Res. 2019, 57, 2083-2103. [CrossRef]

114. Wu, Y.U.N.; Cegielski, C.G.; Hazen, B.T.; Hall, D.J. Cloud Computing in Support of Supply Chain Information System Infrastructure: Understanding When to Go to the Cloud. J. Supply Chain Manag. 2013, 49, 25-41. [CrossRef]

115. Kundu, N. Predictive Analytics to Offer Profitable Anticipatory Shipping for E-Commerce Companies. Int. J. Mod. Agric. 2021, 10, 127-136.

116. Tang, C.S.; Veelenturf, L.P. The Strategic Role of Logistics in the Industry 4.0 Era. Transp. Res. Part E Logist. Transp. Rev. 2019, 129, 1-11. [CrossRef]

117. Barreto, L.; Amaral, A.; Pereira, T. Industry 4.0 Implications in Logistics: An Overview. Procedia Manuf. 2017, 13, 1245-1252. [CrossRef]

118. Kayikci, Y. Sustainability Impact of Digitization in Logistics. Procedia Manuf. 2018, 21, 782-789. [CrossRef]

119. Strandhagen, J.O.; Vallandingham, L.R.; Fragapane, G.; Strandhagen, J.W.; Stangeland, A.B.H.; Sharma, N. Logistics 4.0 and Emerging Sustainable Business Models. Adv. Manuf. 2017, 5, 359-369. [CrossRef]

120. Brouer, B.D.; Karsten, C.V.; Pisinger, D. Big Data Optimization in Maritime Logistics. In Big Data Optimization: Recent Developments and Challenges; Springer: Berlin/Heidelberg, Germany, 2016; pp. 319-344.

121. Al-Rakhami, M.S.; Al-Mashari, M. A Blockchain-Based Trust Model for the Internet of Things Supply Chain Management. Sensors 2021, 21, 1759. [CrossRef] [PubMed]

122. Rodrigue, J.-P.; Notteboom, T. Dry Ports in European and North American Intermodal Rail Systems: Two of a Kind? Res. Transp. Bus. Manag. 2012, 5, 4-15. [CrossRef]

123. Reis, V.; Meier, J.F.; Pace, G.; Palacin, R. Rail and Multi-Modal Transport. Res. Transp. Econ. 2013, 41, 17-30. [CrossRef]

124. Aregall, M.G.; Bergqvist, R.; Monios, J. A Global Review of the Hinterland Dimension of Green Port Strategies. Transp. Res. Part D: Transp. Environ. 2018, 59, 23-34. [CrossRef] 
125. Warshauer, E.; Krosinsky, C. Financing the Transition to Green Infrastructure. In Values at Work; Springer: Berlin/Heidelberg, Germany, 2020; pp. 111-125.

126. Partridge, T. "Power Farmers" in North India and New Energy Producers around the World: Three Critical Fields for Multiscalar Research. Energy Res. Soc. Sci. 2020, 69, 101575. [CrossRef]

127. Li, R.; Su, M. The Role of Natural Gas and Renewable Energy in Curbing Carbon Emission: Case Study of the United States. Sustainability 2017, 9, 600. [CrossRef]

128. Ahjum, F. SADC E-Mobility Outlook: Accelerating Low Carbon Transport Futures. 2020. Available online: https://media africaportal.org/documents/Working-Paper_OP_Fadiel_Transport-and-Energy_20201103_1.pdf (accessed on 25 November 2021).

129. Mete, G. Energy Transitions and the Future of Gas in the EU; Palgrave Macmillan: London, UK, 2019.

130. Jakimowicz, A.; Rzeczkowski, D. The Impact of Public Administration Digitalization on the Decarbonization of the Economy. Energies 2021, 14, 5739. [CrossRef]

131. Borowski, P.F. Digitization, Digital Twins, Blockchain, and Industry 4.0 as Elements of Management Process in Enterprises in the Energy Sector. Energies 2021, 14, 1885. [CrossRef]

132. Lee, K.; Cha, J. Towards Improved Circular Economy and Resource Security in South Korea. Sustainability 2020, 13, 17. [CrossRef]

133. García-Muiña, F.E.; Medina-Salgado, M.S.; Ferrari, A.M.; Cucchi, M. Sustainability Transition in Industry 4.0 and Smart Manufacturing with the Triple-Layered Business Model Canvas. Sustainability 2020, 12, 2364. [CrossRef]

134. Albano, G.L.; Santocchia, M.G. A Case Study on Bid Rigging in Centralized Procurement of Audit Consulting Services in Italy. Available online: https:/ / papers.ssrn.com/sol3/papers.cfm?abstract_id=3905749 (accessed on 25 November 2021).

135. Lajoie-O'Malley, A.; Bronson, K.; van der Burg, S.; Klerkx, L. The Future (s) of Digital Agriculture and Sustainable Food Systems: An Analysis of High-Level Policy Documents. Ecosyst. Serv. 2020, 45, 101183. [CrossRef]

136. Jellason, N.P.; Robinson, E.J.; Ogbaga, C.C. Agriculture 4.0: Is Sub-Saharan Africa Ready? Appl. Sci. 2021, 11, 5750. [CrossRef]

137. Rose, D.C.; Chilvers, J. Agriculture 4.0: Broadening Responsible Innovation in an Era of Smart Farming. Front. Sustain. Food Syst. 2018, 2, 87. [CrossRef]

138. Tal, A. Making Conventional Agriculture Environmentally Friendly: Moving beyond the Glorification of Organic Agriculture and the Demonization of Conventional Agriculture. Sustainability 2018, 10, 1078. [CrossRef]

139. Schmidt, R.; Kirchner, K.; Razmerita, L. Understanding the Business Value of Social Information Systems. In Proceedings of the 53rd Hawaii International Conference on System Sciences (HICSS), Honolulu, HI, USA, 7-10 January 2020. [CrossRef]

140. Pérez-Lara, M.; Saucedo-Martínez, J.A.; Marmolejo-Saucedo, J.A.; Salais-Fierro, T.E.; Vasant, P. Vertical and Horizontal Integration Systems in Industry 4.0. Wirel. Netw. 2020, 26, 4767-4775. [CrossRef]

141. Ciruela-Lorenzo, A.M.; Del-Aguila-Obra, A.R.; Padilla-Meléndez, A.; Plaza-Angulo, J.J. Digitalization of Agri-Cooperatives in the Smart Agriculture Context. Proposal of a Digital Diagnosis Tool. Sustainability 2020, 12, 1325. [CrossRef]

142. Khanna, A.; Kaur, S. Evolution of Internet of Things (IoT) and Its Significant Impact in the Field of Precision Agriculture. Comput. Electron. Agric. 2019, 157, 218-231. [CrossRef]

143. Mogili, U.R.; Deepak, B. Review on Application of Drone Systems in Precision Agriculture. Procedia Comput. Sci. 2018, 133, 502-509. [CrossRef]

144. Shafi, U.; Mumtaz, R.; García-Nieto, J.; Hassan, S.A.; Zaidi, S.A.R.; Iqbal, N. Precision Agriculture Techniques and Practices: From Considerations to Applications. Sensors 2019, 19, 3796. [CrossRef]

145. De Clercq, M.; Vats, A.; Biel, A. Agriculture 4.0: The Future of Farming Technology. Proc. World Gov. Summit Dubai UAE 2018, $1,11-13$.

146. Eashwar, S.; Chawla, P. Evolution of Agritech Business 4.0-Architecture and Future Research Directions. In Proceedings of the IOP Conference Series: Earth and Environmental Science, Surakarta, Indonesia, 24-25 August 2021; IOP Publishing: Bristol, UK, 2021; Volume 775, p. 012011.

147. Reklitis, P.; Sakas, D.P.; Trivellas, P.; Tsoulfas, G.T. Performance Implications of Aligning Supply Chain Practices with Competitive Advantage: Empirical Evidence from the Agri-Food Sector. Sustainability 2021, 13, 8734. [CrossRef]

148. Remondino, M. Agent Based Virtual Tutorship and E-Learning Techniques Applied to a Business Game Built on System Dynamics. In Proceedings of the 8th International Conference on Intelligent Games and Simulation, GAME-ON 2007, Bologna, Italy, 20-22 November 2007; pp. 157-161.

149. Wolfert, S.; Ge, L.; Verdouw, C.; Bogaardt, M.-J. Big Data in Smart Farming-A Review. Agric. Syst. 2017, 153, 69-80. [CrossRef]

150. Mageto, J. Big Data Analytics in Sustainable Supply Chain Management: A Focus on Manufacturing Supply Chains. Sustainability 2021, 13, 7101. [CrossRef]

151. Cravero, A.; Sepúlveda, S. Use and Adaptations of Machine Learning in Big Data-Applications in Real Cases in Agriculture. Electronics 2021, 10, 552. [CrossRef]

152. Alem, H. The Role of Technical Efficiency Achieving Sustainable Development: A Dynamic Analysis of Norwegian Dairy Farms. Sustainability 2021, 13, 1841. [CrossRef]

153. Jin, X.-B.; Yu, X.-H.; Wang, X.-Y.; Bai, Y.-T.; Su, T.-L.; Kong, J.-L. Deep Learning Predictor for Sustainable Precision Agriculture Based on Internet of Things System. Sustainability 2020, 12, 1433. [CrossRef]

154. Rossel, R.A.V.; Bouma, J. Soil Sensing: A New Paradigm for Agriculture. Agric. Syst. 2016, 148, 71-74. [CrossRef]

155. Lu, Y. The Current Status and Developing Trends of Industry 4.0: A Review. Inf. Syst. Front. 2021, 1, 1-20. [CrossRef] 
156. Lezoche, M.; Hernandez, J.E.; del Mar Eva Alemany Díaz, M.; Panetto, H.; Kacprzyk, J. Agri-Food 4.0: A Survey of the Supply Chains and Technologies for the Future Agriculture. Comput. Ind. 2020, 117, 103187. [CrossRef]

157. Fritter, M.S. Development of the Canadian Agri-Food Lifecycle Data Centre with Data Format Interoperability Requirements. Ph.D. Thesis, University of British Columbia, Vancouver, BC, Canada, 2020.

158. Sharma, S.; Solanki, S.; Aswal, K.; Thakur, E.; Malhotra, I. Review on Application of Drone Systems in Agriculture. In Proceedings of the 2021 6th International Conference on Signal Processing, Computing and Control (ISPCC), Solan, India, 7-9 October 2021; IEEE: Piscataway, NJ, USA, 2021; pp. 40-45.

159. Hallett, S.; Hoagland, L.; Toner, E.; Gradziel, T.M.; Mitchell, C.A.; Whipkey, A.L. Urban Agriculture: Environmental, Economic, and Social Perspectives. Hortic. Rev. 2016, 44, 65-120.

160. Kariapper, R.; Razeeth, M.S.S. Internet of Farming (IOF) and Internet of Things (IoT). J. Inf. Syst. Inf. Technol. 2018, 3, $23-35$.

161. Pescosolido, G. Italy's Southern Question: Long-Standing Thorny Issues and Current Problems. J. Mod. Ital. Stud. 2019, 24, 441-455. [CrossRef]

162. Adamashvili, N.; Fiore, M.; Contò, F.; Sala, P.L. Ecosystem for Successful Agriculture. Collaborative Approach as a Driver for Agricultural Development. Eur. Countrys. 2020, 12, 242-256. [CrossRef]

163. Coluccia, B.; Agnusdei, G.P.; Miglietta, P.P.; De Leo, F. Effects of COVID-19 on the Italian Agri-Food Supply and Value Chains. Food Control 2021, 123, 107839. [CrossRef] [PubMed]

164. Nyamah, E.Y.; Jiang, Y.; Feng, Y.; Enchill, E. Agri-Food Supply Chain Performance: An Empirical Impact of Risk. Manag. Decis. 2017, 55, 872-891. [CrossRef]

165. Caracciolo, F.; Amani, P.; Cavallo, C.; Cembalo, L.; D’Amico, M.; Del Giudice, T.; Freda, R.; Fritz, M.; Lombardi, P.; Mennella, L. The Environmental Benefits of Changing Logistics Structures for Fresh Vegetables. Int. J. Sustain. Transp. 2018, 12, 233-240. [CrossRef]

166. Castro, J.A.O.; Jaimes, W.A. Dynamic Impact of the Structure of the Supply Chain of Perishable Foods on Logistics Performance and Food Security. J. Ind. Eng. Manag. 2017, 10, 687-710.

167. Haji, M.; Kerbache, L.; Muhammad, M.; Al-Ansari, T. Roles of Technology in Improving Perishable Food Supply Chains. Logistics 2020, 4, 33. [CrossRef]

168. Li, X. Operations Management of Logistics and Supply Chain: Issues and Directions. Discret. Dyn. Nat. Soc. 2014, 2014, 1-8. [CrossRef]

169. Mentzer, J.T.; DeWitt, W.; Keebler, J.S.; Min, S.; Nix, N.W.; Smith, C.D.; Zacharia, Z.G. Defining Supply Chain Management. J. Bus. Logist. 2001, 22, 1-25. [CrossRef]

170. Musolino, G.; Trecozzi, M.R. Structural Factors for a Third-Generation Port: Planning Interventions for Agri-Food Logistics in Gioia Tauro, Italy. Urban Marit. Transp. XXVII 2021, 204, 43.

171. Malaspina, M. The Agri-Foodstuffs Market and the Value Chain: Proposals for an Integrated System of Multifunction Logistic Centres in the Metropolitan City of Reggio Calabria. In Advanced Engineering Forum; Trans Tech Publication: Stäfa, Switzerland, 2014; Volume 11, pp. 402-409.

172. Russo, F.; Panuccio, P.; Rindone, C. Structural Factors for a Third-Generation Port: Between Hinterland Regeneration and Smart Town in Gioia Tauro, Italy. Urban Marit. Transp. XXVII 2021, $204,79$.

173. Figiel, S.; Gospodarowicz, M.; Grochowska, R.; Kuberska, D.; Kufel-Gajda, J.; Oliński, M.; Wasilewski, A. Innovation Performance of the Polish Agri-Food Sector: Key Determinants and Prospects for Improvements. Monogr. Multi-Annu. Programme 2017. Available online: https:/ / papers.ssrn.com/sol3/papers.cfm?abstract_id=3604974 (accessed on 25 November 2021).

174. Akter, S.; Wamba, S.F.; Gunasekaran, A.; Dubey, R.; Childe, S.J. How to Improve Firm Performance Using Big Data Analytics Capability and Business Strategy Alignment? Int. J. Prod. Econ. 2016, 182, 113-131. [CrossRef]

175. Tao, F.; Sui, F.; Liu, A.; Qi, Q.; Zhang, M.; Song, B.; Guo, Z.; Lu, S.C.-Y.; Nee, A.Y.C. Digital Twin-Driven Product Design Framework. Int. J. Prod. Res. 2018, 57, 3935-3953. [CrossRef]

176. Adamashvili, N.; State, R.; Tricase, C.; Fiore, M. Blockchain-Based Wine Supply Chain for the Industry Advancement. Sustainability 2021, 13, 13070. [CrossRef]

177. De Raeve, P.; Gomez, S.; Hughes, P.; Lyngholm, T.; Sipilä, M.; Kilanska, D.; Hussey, P.; Xyrichis, A.; ENS4Care Project. Enhancing the Provision of Health and Social Care in Europe through EH Ealth. Int. Nurs. Rev. 2017, 64, 33-41. [CrossRef] [PubMed]

178. Guttentag, D.A. Virtual Reality: Applications and Implications for Tourism. Tour. Manag. 2010, 31, 637-651. [CrossRef]

179. Remondino, M. Virtual Reality and Immersive Simulation Technology Outside Video Gaming: Enterprise Applications and Potential Implications. Int. J. Simul. Syst. Sci. Technol. 2017, 18, 11.1-11.12. [CrossRef]

180. Karlin, S.; Karlin, S.; Karlin, S. Jared Leto Tours the Arctic in A New Virtual Reality Climate Change Campaign. Available online: https:/ / www.fastcompany.com/3052044/jared-leto-tours-the-arctic-in-a-new-virtual-reality-climate-change-campaign (accessed on 23 March 2018).

181. Remondino, M. A Managerial Perspective of Technological Cloud Paradigms: Its Effects on Enterprise Business, Costs and Strategies. Int. J. Simul. Syst. Sci. Technol. 2017, 18, 1-12. [CrossRef]

182. Spanaki, K.; Karafili, E.; Sivarajah, U.; Despoudi, S.; Irani, Z. Artificial Intelligence and Food Security: Swarm Intelligence of AgriTech Drones for Smart AgriFood Operations. Prod. Plan. Control 2021, 1-19. Available online: https://bradscholars.brad.ac uk/bitstream/handle/10454/17961/Acceptedversion-PPCFinalSwarmintelligence.pdf? sequence=7\&isAllowed=y (accessed on 25 November 2021). 
183. Daponte, P.; De Vito, L.; Glielmo, L.; Iannelli, L.; Liuzza, D.; Picariello, F.; Silano, G. A Review on the Use of Drones for Precision Agriculture. In Proceedings of the IOP Conference Series: Earth and Environmental Science, Malang City, Indonesia, 12-13 March 2019; IOP Publishing: Bristol, UK, 2019; Volume 275, p. 012022.

184. Iost Filho, F.H.; Heldens, W.B.; Kong, Z.; de Lange, E.S. Drones: Innovative Technology for Use in Precision Pest Management. J. Econ. Entomol. 2020, 113, 1-25. [CrossRef] [PubMed]

185. Stehr, N.J. Drones: The Newest Technology for Precision Agriculture. Nat. Sci. Educ. 2015, 44, 89-91. [CrossRef] 